\title{
Resistance to Methicillin in Coagulase-negative Staphylococci and Its Detection
}

\author{
Milan Kolár $\check{r}^{1}$, Jan Bardon̆ ${ }^{1,2}$, Vojtěch Hanulík ${ }^{1}$, Pavel Sauer ${ }^{1}$, Vladimír Babák³, \\ Jarmila Schlegelová3 \\ ${ }^{1}$ Department of Microbiology, Faculty of Medicine and Dentistry, Palacký University in Olomouc, \\ Czech Republic \\ ${ }^{2}$ State Veterinary Institute Olomouc, Czech Republic \\ ${ }^{3}$ Veterinary Research Institute, Brno, Czech Republic
}

Received January 8, 2008

Accepted September 8, 2009

\begin{abstract}
Resistance of staphylococci to methicillin is important especially in the case of Staphylococcus aureus isolates. Its impact in veterinary medicine is not exactly specified in coagulase-negative staphylococci; however, these staphylococci may represent an important reservoir of resistance genes.

The study aimed at detecting resistance to methicillin in coagulase-negative staphylococci from raw materials and foodstuffs of animal origin and assessing the tests frequently used to determine this resistance.

Coagulase-negative staphylococci (198 isolates of 12 species) were tested. Resistance to methicillin was determined by the disk diffusion method using oxacillin and cefoxitin disks, microdilution method, detection of PBP2a and the mecA gene. Of the tested isolates, 109 (55.1\%) were classified as resistant by the diffusion test with oxacillin, 32 isolates $(16.2 \%)$ by the test with cefoxitin and 50 isolates $(25.3 \%)$ on the basis of oxacillin minimum inhibitory concentration (MIC). No resistant isolates were incorrectly identified as susceptible when using the disk diffusion method with oxacillin (sensitivity of 100\%). However, apart from 22 correctly classified resistant isolates, another 87 isolates were incorrectly identified as resistant as well (specificity of $50.6 \%$ ). The test with cefoxitin showed the lowest $(45.5 \%)$ sensitivity in determination of resistant isolates. By contrast, this test was the most precise in classification of resistant isolates (specificity of $87.5 \%$ ). When using the microdilution method, resistant strains were identified with the sensitivity and specificity of $68.2 \%$ and $80.1 \%$, respectively.

The results revealed substantial variability of methicillin-resistant isolates ranging from $16.2 \%$ to $55.1 \%$, depending on the phenotyping methods and recommended interpretation criteria used. Therefore, it is advisable to reconsider the current interpretation criteria in the case of coagulasenegative staphylococci of animal origin (with the exception of $S$. epidermidis).
\end{abstract}

Coagulase-negative staphylococci, animals, resistance, methicillin

One of the current problems in both human and veterinary medicine is bacterial resistance to antimicrobial agents. The failure to treat infectious diseases caused by resistant bacteria leads to increased morbidity and mortality and also poses a serious epidemiological risk. Moreover, the economic impact is not negligible. From the point of view of clinical importance of antibiotic resistance, the most important bacteria are, among others, methicillin-resistant strains of Staphylococcus aureus (MRSA) and coagulase-negative staphylococci.

The importance of methicillin-resistant coagulase-negative staphylococci in veterinary medicine has not been defined. However, these strains may represent a reservoir of resistance genes (Vengust et al. 2006; Busscher et al. 2006), which is why they are so important. Coagulase-negative staphylococci are considered to be major pathogens causing mastitis, resulting in farmers' economic losses. They may also be isolated from infections in other animal species, such as poultry, dogs, cats and pigs (Aarestrup and Schwarz 2006).

Resistance to oxacillin/methicillin is determined by the presence of the mec $A$ gene encoding penicillin-binding protein $2 \mathrm{a}$ (PBP2a) with very low affinity to beta-lactam

Address for correspondence:

MVDr. Jan Bardoň, Ph.D., MBA

State Veterinary Institute Olomouc

Jakoubka ze Stříbra 1

Phone: +420585225641

77900 Olomouc, Czech Republic

E-mail: jbardon@svuol.cz

http://www.vfu.cz/acta-vet/actavet.htm 
antibiotics (Chambers 1997). Detection of the mecA gene by PCR or PBP2a by latexagglutination test may explicitly identify methicillin-resistant strains (Hájek et al. 2002; van Leeuwen et al. 1999). Identification is problematic if the disk diffusion or microdilution methods are used and isolates are classified according to interpretation criteria. For coagulase-negative staphylococci, with the exception of $S$. lugdunensis, different interpretation criteria are stated by the Clinical and Laboratory Standards Institute document (CLSI 2007) than for $S$. aureus (MIC $0.25 \mathrm{mg} / 1$ and $2 \mathrm{mg} / 1$, respectively). Moreover, such resistance is based predominantly on examination of human isolates. Therefore, the objective of this study was to determine the resistance to methicillin in coagulase-negative staphylococci from raw materials and foodstuffs of animal origin and to assess the accuracy of five tests frequently used to determine resistance to methicillin: 1) mecA gene detection as a reference, 2) and 3) oxacillin and cefoxitin disk tests, respectively (inhibition zone sizes), 4) microdilution test (MIC to oxacillin) and 5) PBP2a detection for non-human coagulase-negative staphylococci isolates. Sensitivity, specificity and interpretation criteria of the above-mentioned methods for 12 species of coagulase-negative staphylococci were evaluated.

\section{Materials and Methods}

Staphylococcal isolates

Coagulase-negative staphylococci (198 isolates) from raw materials and foodstuffs of animal origin were collected in 2003-2006. The samples were taken from milk (both fresh and pasteurized), dairy products (cheese, butter) and swabs from dairy technology.

The scheme of identification established in the laboratory: Analytical samples from raw materials and foodstuffs of animal origin were cultured in parallel on Baird-Parker agar (Merck, Darmstadt, Germany) and KRANEP agar (Merck). A maximum of five suspect morphologically dissimilar colonies of Staphylococcus spp. were cultured on blood agar plates containing 5\% sheep blood and identified using the catalase test, oxi test, bacitracin and furazolidone susceptibility disk diffusion tests and coagulase test, and, biochemically by the STAPHYtest 24 identification system (Pliva-Lachema, Brno, Czech Republic). Isolates of the same species from a single sample were not undertaken in this study. The isolates, belonging to 12 species of staphylococci, were stored in tryptone soya broth (TSB; Oxoid, Basingstoke, UK) supplemented with $20 \%$ glycerol at $-80{ }^{\circ} \mathrm{C}$ until studied.

Tests for the determination of resistance to methicillin

As recommended by B arry and Thornsberry (1991), for the identification of methicillin-resistant $S$. aureus strains, oxacillin should be preferred to cloxacillin, methicillin and other penicillinase-resistant antibiotics. Therefore, oxacillin, not methicillin, was used in the compared tests. The MIC values for staphylococci to oxacillin were determined by the standard microdilution method (CLSI 2007) with oxacillin concentrations ranging from 0.03 to $4 \mathrm{mg} / \mathrm{l}$. The MIC susceptibility/resistance interpretation criterion was defined as a concentration of $0.25 \mathrm{mg} / \mathrm{l}$, based on the CLSI guidelines (CLSI 2007). Reference strains Staphylococcus aureus ATCC 29213 and Enterococcus faecalis ATCC 29212 served for protocol quality control. Furthermore, two disk diffusion methods were used, with $1 \mu \mathrm{g}$ oxacillin (Oxoid) and $30 \mu \mathrm{g}$ cefoxitin (Oxoid) disks using Mueller-Hinton agar (Trios, Prague, Czech Republic). Resistant isolates were identified based on inhibition zone sizes of $\leq 17 \mathrm{~mm}$ for oxacillin and $\leq 24 \mathrm{~mm}$ for cefoxitin, respectively (CLSI 2007). Reference strain Staphylococcus aureus ATCC 25923 was used for quality control of the disk methods. Detection of PBP2a by latex agglutination (Cavassini et al. 1999; Felten et al. 2002) was performed with the MRSA-Screen test (Denka Seiken Co., Japan). The PBP2a detection was confirmed by the mecA gene detection by PCR (primers $m e c A-\mathrm{F}: 5^{\prime}$-TCCAGATTACAACTTCACCAGG-3' and mecA-R:5'-CCACTTCATATCTTGTAACG-3'; Oliveira and De Lencastre 2002) using a modified approach (Sauer et al. 2008). Template DNA was obtained by lysis of cells from bacterial culture induced by boiling. Briefly, isolates were grown on blood agar (Trios) for $24 \mathrm{~h}$, one single colony was picked up, resuspended in $100 \mu \mathrm{l}$ of sterile deionised water and heated at $99{ }^{\circ} \mathrm{C}$ for $15 \mathrm{~min}$ under mild shaking in the Thermomixer comfort (Eppendorf). Then the tubes were centrifuged (1006 $\mathrm{g}, 5 \mathrm{~min})$ to sediment ballast material whereas the supernatant containing crude extract of bacterial DNA was used.

When assessing the methods, the mecA gene detection was considered the gold standard for identification of methicillin-resistant isolates.

Evaluation of tests

The tests were compared on the basis of correct and incorrect identification of resistant and susceptible isolates. The following indicators were used: 1) specificity - the ability of a test to detect truly susceptible isolates, and 2) sensitivity - the ability of a test to detect truly resistant isolates. Identification of false-susceptible isolates with respect to the gold standard was considered as a major error and of false-resistant isolates as a minor error. 


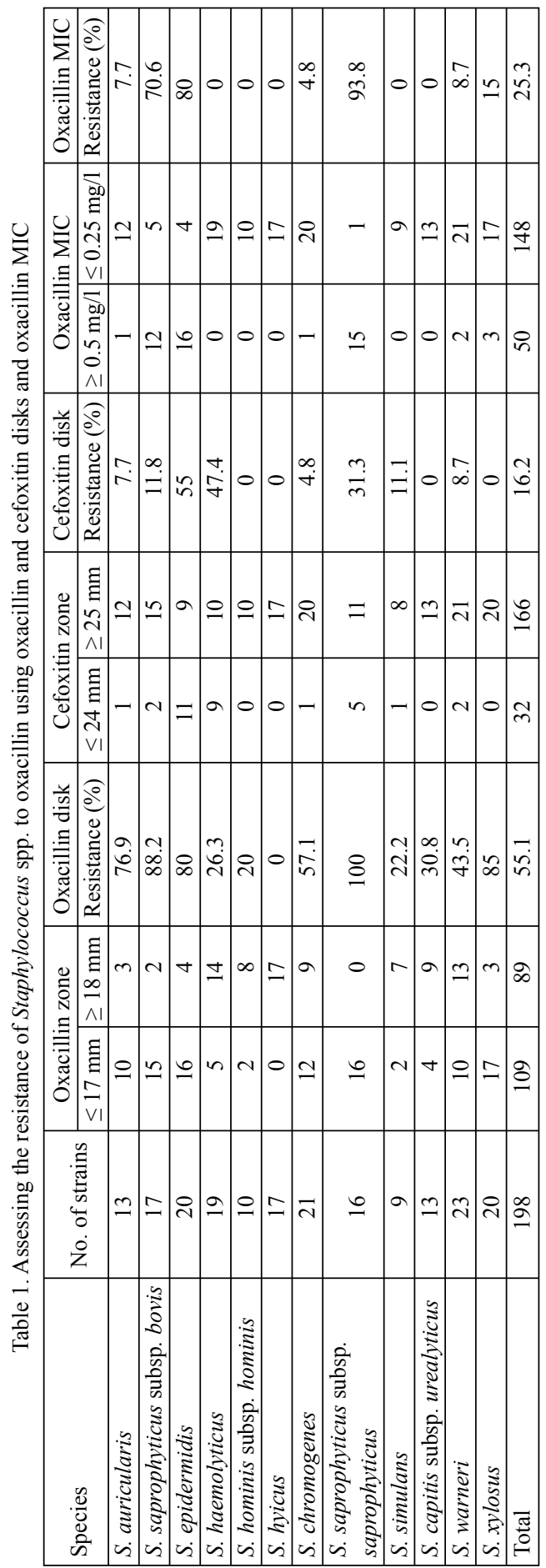

\section{Results}

The results of assessing methicillinresistance by the individual tests in 12 species of staphylococci are shown in Table 1. Of the 198 isolates, 109 isolates (55.1\%) were found to be resistant by the diffuse test with oxacillin and 32 isolates $(16.2 \%)$ by the cefoxitin test. Based on the oxacillin MIC, resistance to methicillin was detected in 50 strains (25.3\%). The abovementioned results suggest a considerable variability of oxacillin-resistant isolates, ranging from $16.2 \%$ to $55.1 \%$, depending on the phenotyping method used and recommended interpretation criteria.

Evaluation of the results of individual tests used for determining the resistance to oxacillin is shown in Table 2. The mecA gene was detected in 22 strains $(11.1 \%)$, of which 15 were $S$. epidermidis, four S. capitis subsp. urealyticus and three S. warneri. The method for detecting the resistance to oxacillin/methicillin on the basis of PBP2a detection was $100 \%$ consistent with the mecA gene detection. Disk diffusion tests with both oxacillin and cefoxitin as well as the microdilution test with oxacillin MIC determination yielded both false-susceptible and falseresistant results. No resistant isolates were incorrectly identified as susceptible using the disk diffusion method with oxacillin (sensitivity of $100 \%$ ). However, in addition to 22 correctly identified resistant isolates, another 87 isolates were incorrectly identified as resistant (a minor error; specificity of 50.6\%). The other test, with cefoxitin, yielded the lowest sensitivity in determination of resistant isolates $(45.5 \%)$. This means that 12 resistant isolates were incorrectly classified as susceptible (a major error). On the other hand, of the compared tests, this test was the best at classifying resistant isolates (specificity of $87.5 \%$ ).

The results of determining MIC to oxacillin for the individual staphylococcal species are given in Table 3. A total of 50 isolates were classified as resistant (R) as their MIC was $\geq 0.5 \mathrm{mg} / \mathrm{l}$. The species 
Table 2. Analysis of the accordance and divergence (n isolates) in classification of 198 Staphylococcus spp. isolates as resistant $(\mathrm{R})$ or susceptible $(\mathrm{S})$ by the compared tests with reference $m e c A$ gene detection

\begin{tabular}{|c|c|c|c|c|c|c|c|c|c|c|c|c|c|c|c|}
\hline \multirow{4}{*}{ Species } & \multirow{4}{*}{$\mathrm{n}$} & \multicolumn{14}{|c|}{ Compared tests } \\
\hline & & \multirow{3}{*}{ mecA } & \multirow{3}{*}{ PBP2a } & \multicolumn{4}{|c|}{ Oxacillin disk } & \multicolumn{4}{|c|}{ Cefoxitin disk } & \multicolumn{4}{|c|}{ Oxacillin MIC } \\
\hline & & & & \multicolumn{2}{|c|}{ accordance $^{\mathrm{a}}$} & \multicolumn{2}{|c|}{ false } & \multicolumn{2}{|c|}{ accordance $^{\mathrm{a}}$} & \multicolumn{2}{|c|}{ false } & \multicolumn{2}{|c|}{ accordance $^{\mathrm{a}}$} & \multicolumn{2}{|c|}{ false } \\
\hline & & & & $\mathrm{R}$ & $\mathrm{S}$ & $\mathrm{R}$ & $\mathrm{S}$ & $\mathrm{R}$ & $\mathrm{S}$ & $\mathrm{R}$ & $\mathrm{S}$ & $\mathrm{R}$ & $\mathrm{S}$ & $\mathrm{R}$ & $\mathrm{S}$ \\
\hline S. auricularis & 13 & 0 & 0 & 0 & 3 & 10 & 0 & 0 & 12 & 1 & 0 & 0 & 12 & 1 & 0 \\
\hline S. saprophyticus subsp. bovis & 17 & 0 & 0 & 0 & 2 & 15 & 0 & 0 & 15 & 2 & 0 & 0 & 5 & 12 & 0 \\
\hline S. epidermidis & 20 & 15 & 15 & 15 & 4 & 1 & 0 & 10 & 4 & 1 & 5 & 15 & 4 & 1 & 0 \\
\hline S. haemolyticus & 19 & 0 & 0 & 0 & 14 & 5 & 0 & 0 & 10 & 9 & 0 & 0 & 19 & 0 & 0 \\
\hline S. hominis subsp. hominis & 10 & 0 & 0 & 0 & 8 & 2 & 0 & 0 & 10 & 0 & 0 & 0 & 10 & 0 & 0 \\
\hline S. hyicus & 17 & 0 & 0 & 0 & 17 & 0 & 0 & 0 & 17 & 0 & 0 & 0 & 17 & 0 & 0 \\
\hline S. chromogenes & 21 & 0 & 0 & 0 & 9 & 12 & 0 & 0 & 20 & 1 & 0 & 0 & 20 & 1 & 0 \\
\hline S. saprophyticus subsp. saprophyticus & 16 & 0 & 0 & 0 & 0 & 16 & 0 & 0 & 11 & 5 & 0 & 0 & 1 & 15 & 0 \\
\hline \begin{tabular}{|l} 
S. simulans \\
\end{tabular} & 9 & 0 & 0 & 0 & 7 & 2 & 0 & 0 & 8 & 1 & 0 & 0 & 9 & 0 & 0 \\
\hline S. capitis subsp. urealyticus & 13 & 4 & 4 & 4 & 9 & 0 & 0 & 0 & 9 & 0 & 4 & 0 & 9 & 0 & 4 \\
\hline S. warneri & 23 & 3 & 3 & 3 & 13 & 7 & 0 & 0 & 18 & 2 & 3 & 0 & 18 & 2 & 3 \\
\hline S. xylosus & 20 & 0 & 0 & 0 & 3 & 17 & 0 & 0 & 20 & 0 & 0 & 0 & 17 & 3 & 0 \\
\hline Total & 198 & 22 & 22 & 22 & 89 & 87 & 0 & 10 & 154 & 22 & 12 & 15 & 141 & 35 & 7 \\
\hline
\end{tabular}

MIC - minimum inhibitory concentration; accordance ${ }^{\mathrm{a}}$ - accordance in classification of isolates as susceptible (S) or resistant (R) with the reference method of the mecA gene detection

Table 3. Oxacillin MIC values in isolates of 198 coagulase-negative staphylococci from raw materials and foodstuffs of animal origin

\begin{tabular}{|l|c|r|r|r|r|c|}
\hline \multirow{2}{*}{ Species } & \multirow{2}{*}{ No. of isolates } & \multicolumn{5}{|c|}{ Oxacillin MIC (mg/l) } \\
\cline { 3 - 7 } & & $\leq 0.125$ & 0.25 & 0.5 & 1 & 2 \\
\hline S. auricularis & 13 & - & 12 & 1 & - & - \\
\hline S. saprophyticus subsp. bovis & 17 & - & 5 & 9 & 3 & - \\
\hline S. epidermidis & 20 & - & 4 & - & 7 & 9 \\
\hline S. haemolyticus & 19 & - & 19 & - & - & - \\
\hline S. hominis subsp. hominis & 10 & - & 10 & - & - & - \\
\hline S. hyicus & 17 & - & 17 & - & - & - \\
\hline S. chromogenes & 21 & 18 & 2 & 1 & - & - \\
\hline $\begin{array}{l}\text { S. saprophyticus subsp. } \\
\text { saprophyticus }\end{array}$ & 16 & - & 1 & 13 & 2 & - \\
\hline S. simulans & 9 & 9 & - & - & - & - \\
\hline S. capitis subsp. urealyticus & 13 & 13 & - & - & - & - \\
\hline S. warneri & 23 & 9 & 12 & 1 & - & 1 \\
\hline S. xylosus & 20 & 8 & 9 & 3 & - & - \\
\hline Total & 198 & 57 & 91 & 28 & 12 & 10 \\
\hline
\end{tabular}

were as follows: S. epidermidis $(32 \%), \quad$ S. saprophyticus subsp. saprophyticus (30\%), $S$. saprophyticus subsp. bovis (24\%), S. xylosus (6\%), S. warneri (4\%), S. chromogenes $(2 \%)$ and $S$. auricularis (2\%). With the microdilution method, resistant isolates were classified with $68.2 \%$ sensitivity and $80.1 \%$ specificity; however, the method also produced minor (35 isolates) and major errors (7 isolates).

In the case of $S$. epidermidis isolates, the presence of PBP2a and the mecA gene was detected in $15(93.8 \%)$ out of 16 isolates with oxacillin MIC $\geq 0.5 \mathrm{mg} / \mathrm{l}$. As for the other coagulase-negative staphylococcal species with oxacillin MIC $\geq 0.5 \mathrm{mg} / 1$ (34 isolates), the presence of PBP2a was not detected in any of them. By contrast, the presence of PBP2a was detected in 7 isolates with oxacillin MIC ranging from 0.125 to $0.25 \mathrm{mg} / \mathrm{l}$ (four isolates of $S$. capitis subsp. urealyticus and three of S. warneri).

\section{Discussion}

The breakpoint or cut-off values for classification of methicillin-resistant staphylococci are crucial values to assessing this type of resistance. The CLSI recommendations (CLSI 2007) state the values of $2 \mathrm{mg} / \mathrm{l}$ for $S$. aureus strains and $0.25 \mathrm{mg} / \mathrm{l}$ for coagulase-negative 
staphylococci (except for S. lugdunensis). The recommendations are supported by the study by Hájek et al. (2002) who reported that $29 \%$ of $S$. epidermidis isolates with MIC to oxacillin of $2 \mathrm{mg} / \mathrm{l}$ and classified as susceptible according to the accepted criteria (MIC $\mathrm{R} \geq 4 \mathrm{mg} / \mathrm{l}$ ) were carriers of the mecA gene. The oxacillin breakpoint value of $0.25 \mathrm{mg} / \mathrm{l}$ for coagulase-negative staphylococci was recommended by Tenover et al. (1999). They discovered that with the breakpoint of $2 \mathrm{mg} / 1,38-74 \%$ of $m e c A$-positive strains (depending on the media used) were incorrectly classified as susceptible whereas with the breakpoint of $0.25 \mathrm{mg} / \mathrm{l}$, classification errors were in the range of $6-16 \%$ only. A the same time, however, the authors warn of potential false resistance in $m e c A$-negative strains of certain species, in particular S. warneri, S. capitis, S. lugdunensis and S. saprophyticus.

This study suggests that $100 \%$ of coagulase-negative staphylococci (with the exception of $S$. epidermidis isolates) of animal origin with the oxacillin MIC range of $0.5-2 \mathrm{mg} / \mathrm{l}$ were incorrectly classified as resistant. By contrast, in $S$. epidermidis isolates with the abovementioned oxacillin MIC range, the presence of the mecA gene and PBP2a was detected in $94 \%$. Therefore, it is difficult to define a single MIC value as a precise criterion of resistance for all coagulase-negative staphylococci. For human isolates (except for S. lugdunensis), a single MIC value is recommended as the most appropriate, namely $0.25 \mathrm{mg} / \mathrm{l}$ (CLSI 2007). In such assessment, a major error, i.e. resistant isolates being incorrectly classified as susceptible, is considered unacceptable. Hussain et al. (2000) reported that in the most frequent human isolates of coagulase-negative staphylococci, such as $S$. epidermidis, $S$. haemolyticus and $S$. hominis, oxacillin MIC was $\geq 0.5 \mathrm{mg} / 1$ in cases of positive detection of the mec $A$ gene. However, our data show that in coagulase-negative staphylococci of animal origin, the value of $0.25 \mathrm{mg} / \mathrm{l}$ is only valid for $S$. epidermidis. For the other species, $1 \mathrm{mg} / \mathrm{l}$ appears to be more appropriate. When using this value, only 1 out of $178(1 \%)$ coagulasenegative staphylococci, with the exception of $S$. epidermidis, were false-resistant and 7 strains $(4 \%)$ were false-susceptible.

Of the compared conventional phenotype tests for identification of methicillinresistant isolates of coagulase-negative staphylococci, with respect to identification of resistant isolates (specificity of $87.5 \%$ ), the screening method using a cefoxitin disk is viewed as the most appropriate test. It must be mentioned that 22 strains from the group of 198 strains were classified as false-resistant and 12 isolates as false-susceptible. Swenson et al. (2005) also reported false-susceptible and false-resistant isolates in the case of coagulase-negative staphylococci and the test with cefoxitin. The question is whether, in the case of coagulase-negative staphylococci of animal origin (with the exception of $S$. epidermidis), the size of cefoxitin zone used for determination of resistance should also be adjusted.

The study results suggest that also in veterinary practice it is advisable, when indicated, to confirm resistance to oxacillin, e.g. using PBP2a detection by latex agglutination. Although the method was primarily used to detect methicillin-resistance of $S$. aureus, it could be used for coagulase-negative staphylococci as well (Louie et al. 2001). This fact was confirmed by our study. In all strains of coagulase-negative staphylococci with the positively detected $m e c A$ gene, the test for the presence of PBP2a was also positive.

\section{Rezistence k methicilinu u koaguláza-negativních stafylokoků a její detekce}

Rezistence stafylokoků $\mathrm{k}$ methicilinu je významná především v prípadě izolátů Staphylococcus aureus, u koaguláza-negativních stafylokoků není její dopad ve veterinární medicíně přesně specifikován, tyto kmeny však mohou představovat důležitý rezervoár genů rezistence. Cílem předložené práce bylo stanovit rezistenci koaguláza-negativních stafylokoků izolovaných z potravin a surovin živočišného původu (mléko a mléčné výrobky) k oxacilinu a zhodnotit možnosti detekce této rezistence. 
Celkem bylo testováno 198 koaguláza-negativních stafylokoků. Stanovení rezistence $\mathrm{k}$ methicilinu bylo provedeno difuzní diskovou metodou za použití disku oxacilinu a cefoxitinu, diluční mikrometodou, průkazem PBP2a a genu mecA. Ze 198 testovaných izolátů bylo $\mathrm{v}$ difuzním testu s oxacilinem určeno jako rezistentní 109 izolátů $(55,1 \%)$, v testu s cefoxitinem 32 izolátů (16,2\%) a podle minimální inhibiční koncentrace oxacilinu 50 izolátů $(25,3 \%)$. Žádný rezistentní izolát nebyl mylně identifikován jako citlivý diskovou difuzní metodou s oxacillinem (senzitivita 100 \%). Avšak kromě 22 správně klasifikovaných rezistentních izolátů bylo dalších 87 izolátů mylně identifikováno rovněž jako rezistentní (specificita 50,6\%). Test s cefoxitinem vykazoval nejnižší senzitivitu stanovení rezistentních izolátů $(45,5 \%)$. Naopak rezistentní izoláty byly tímto testem klasifikovány nejsprávněji (specificita 87,5\%). Za použití mikrodiluční metody byly rezistentní izoláty klasifikovány se senzitivitou $68,2 \%$ a specificitou $80,1 \%$.

$\mathrm{Z}$ výsledků vyplynula značná variabilita $\mathrm{v}$ detekci methicilin-rezistentních izolátů v závislosti na použité fenotypové metodě a doporučených interpretačních kritériích, a to od $16,2 \%$ do $55,1 \%$. Je tedy zřejmé, že v prrípadě koaguláza-negativních stafylokoků animální provenience (s výjimkou $S$. epidermidis) je vhodné zvážit stávající interpretační kritéria.

\section{Acknowledgement}

The study was supported by the Czech Ministry of Education, Youth and Sports project No. MSM 6198959223 and by the Ministry of Agriculture projects No. 1B53018 and NAZV QH 91231.

\section{References}

Aarestrup FM, Schwarz S 2006: Antimicrobial resistance in staphylococci and streptococci of animal origin. In Aarestrup et al. Antimicrobial resistance in bacteria of animal origin. ASM Press, Washington DC. pp. 187-212

Barry AL, Thornsberry C 1991: Susceptibility test: diffusion test procedures, In: Balows A, Hazsler WJ, Herrmann KL, Isenberg HD, Shadomy HJ (Eds): Manual of Clinical Microbiology, $5^{\text {th }}$ ed., Am Soc Microbiol, Washington, pp. 463-474

Busscher JF, Van Duijkeren E, Sloet Van Oldruitenborgh-Oosterbaan MM 2006: The prevalence of methicillinresistant staphylococci in healthy horses in the Netherlands. Vet Microbiol 113: 131-136

Cavassini M, Wenger A, Jaton K, Blanc DS, Bille J 1999: Evaluation of MRSA-Screen, a simple anti-PBP 2a slide latex agglutination kit, for rapid detection of methicillin resistance in Staphylococcus aureus. J Clin Microbiol 37: 1591-1594

Clinical and Laboratory Standards Institute 2007: Performance Standards for Antimicrobial Susceptibility Testing; Seventeenth Informational Supplement. CLSI document M100-S17. Clinical and Laboratory Standards Institute, 940 West Valley Road, Suite 1400, Wayne, Pennsylvania 19087-1898 USA

Chambers HF 1997: Methicillin resistance in staphylococci: molecular and biochemical basis and clinical implications. Clin Microbiol Rev 10: 781-791

Felten A, Grandry B, Lagrange PH, Casin I 2002: Evaluation of three techniques for detection of low-level methicillin-resistant Staphylococcus aureus (MRSA): A disk diffusion method with cefoxitin and moxalactam, the Vitek 2 system, and the MRSA-screen latex agglutination test. J Clin Microbiol 40: 2766-2771

Hájek V, Pantůček R, Kolář M, Doškař J, Rozsypal S 2002: Comparison of MRSA-Screen latex agglutination, conventional phenotypic methods and $m e c A$ gene detection for identification of oxacillin resistance in staphylococci. Biologia 57: 729-738

Hussain Z, Stoakes L, Massey V, Diagre D, Fitzgerald V, El Sayed S, Lannigan R 2000: Correlation of oxacillin MIC with $m e c A$ gene carriage in coagulase-negative staphylococci. J Clin Microbiol 38: 752-754

Louie L, Majury A, Goodfellow J, Louie M, Simor AE 2001: Evaluation of a latex agglutination test (MRSAScreen) for detection of oxacillin resistance in coagulase-negative staphylococci. J Clin Microbiol 39: 4149-4151

Oliviera DC, de Lencastre H 2002: Multiplex PCR strategy for rapid identification of structural types and variants of the mec element in methicillin-resistant Staphylococcus aureus. Antimicrob Agents Chemother 46: 2155-2161

Sauer P, Síla J, Štosová T, Večeřová R, Hejnar P, Vágnerová I, Kolář M, Raclavský V, Petrželová J, Lovečková Y, Koukalová D 2008: Prevalence of genes encoding extracellular factors among methicillin-resistant Staphylococcus aureus isolates from the University Hospital, Olomouc, Czech Republic. J Med Microbiol 57: $403-410$ 
Swenson JM, Tenover FC, Cefoxitin Disk Study Group 2005: Results of disk diffusion testing with cefoxitin correlate with presence of mecA in Staphylococcus spp. J Clin Microbiol 43: 3818-3823

Tenover FC, Jones RN, Swenson JM, Zimmer B, McAllister S, Jorgensen JH 1999: Methods for improved detection of oxacillin resistance in coagulase-negative staphylococci: Results of a multicenter study. J Clin Microbiol 37: 4051-4058

van Leeuwen WB, van Pelt C, Luijendijk A, Verbrugh HA, Goessenns WHF 1999: Rapid detection of methicillin resistance in Staphylococcus aureus isolates by the MRSA-Screen latex agglutination test. J Clin Microbiol 37: $3029-3030$

Vengust M, Anderson MEC, Rousseau J, Weese JS 2006: Methicillin-resistant staphylococcal colonization in clinically normal dogs and horses in the community. Lett Appl Microbiol 43: 602-606 